\title{
ЈЕЗИЧКЕ КОНСТАНТЕ У КОНТЕКСТУ ДЕФИНИЦИЈЕ ПОЈМА „РЕЗУЛТАТ ГЛОБАЛИЗАЦИЈЕ” И ЮЕГОВЕ ЕВАЛУАТИВНЕ УПОТРЕБЕ**
}

\begin{abstract}
Рад износи резултате испитивања синтаксичке конструкције којом се једна претпостављена реченица кондензује у лексему категорије адверба (енгл. reportedly и српски наводно), налазећи се као идентична у два језика - у енглеском и у српском језику, а у светлу у социолингвистици много истицане релевантне и доминантне улоге првог језика у процесима тзв. глобализације. Из перспективе детаља у категорији семантичко-синтаксичких конструкција, полазећи од пресумпције утицаја датог процеса, а на основи општелингвистичке методологије посматрања језичких феномена, аутор показује чињеницу аутохтоности оваквих конструкција у језицима исте индоевропске групе језика, као и чињеницу да је њихов паралелизам у најмање два (па и више) језика резултат постојања језичких константи - како их је давно дефинисао српски лингвиста А. Белић.

Кључне речи: глобализација, језичке константе, енглески, српски, утицај, reportedly, наводно, аутохтоност, паралелизам
\end{abstract}

1. Иако наслов рада упућује на помисао да ће у њему бити резултати истраживања општих односа процеса који се подразумева под термином „глобализација" и манифестација утицаја тога процеса на језик наше (српске) друштвене средине, нагласићу да рад анализира врло узак домен потенцијалног остваривања / неостваривања датога процеса. Ово је утолико потребније констатовати у друштвеним околностима у којима је видљива, како би се терминима социолингвистике формулисало - тенденција да се лаичкој популацији говорника мањег („слабијег”) језика сугерише постојање опасности које процес у питању доноси (нпр. опасност губљења идентитета, потчињавања већем, дакле ,јачем” језику и култури која је његов носилац и сл.).

\footnotetext{
${ }^{*}$ slstanojcic@gmail.com

** Рад је у оквиру пројекта 178014 „Динамика структура савременог српског језика”, који финансира Министарство просвете, науке и технолошког развоја Републике Србије.
} 
Тај уски домен стављам у оквире анализе дискурса (текстлингвистике) као - употребу и подударање лексичко-синтаксичких фразема у (најмање) два језика. И то - посматране из перспективе само једног примера из ове категорије језичких јединица, и са тезом да, и у условима стварног постојања гл о бал и за ц и е (шта год се подразумевало под овим термином), не мора баш све бити тумачено као резултат утицаја једног језика на други, највише (и логично) - утицаја већег језика на мањи. Притом, тежиште рада није на тумачењу значења ових фразема, него је на чињеници паралелности многих - аутохтон их за два језика из којих их узимамо - семантичко-синтаксичких јединица.

Наравно, одређени број типова конструкције из другог језика може бити и (активна) честица која ће бити иницијални моменат у настајању и експанзији дате конструкције у нашем језику. Али - и тада та конструкција не мора бити проста копија „увезене”, него је резултат процеса омогућеног језичким потенцијалима нашег језика, међу њима и константама које постоје у свим језицима.

2. У овој прилици, разматраћемо енглески језик у односу на српски језик - посебно с обзиром на праву природу односа вишејезичности са феноменом гл о ба л и з а ц и ј е, који је врло много - како пише Р. Бугарски - „посматран и расправљан као један од најважнијих економских и политичких догађаја последњих петнаестак година” и који је „имао [...] као свој главни језички сигнал убрзану експанзију енглеског широм света” (Бугарски 2009: 15-16). Зато погледајмо енглеску лексему из класе адверба reportedly према српској лексеми наводно из исте класе речи.

(a) Са аспекта творбе речи, енглеска лексема је добијена као девербатив уобличен у прилог суфиксом -ly (који је и иначе граматичко-творбена ознака енглеског адверба); српска лексема добијена је трансформисањем девербативно изведеног придева са суфиксом -(a)н/u/, -на, -но (наводи[-ти], наводи[-м] + -ни, -на, -но... > наводан, наводна, наводно) - функционално - у прилог тако што је за ознаку припадности овој врсти речи узет облик cp. p. једнине (са његовом морфолошком карактеристиком: акцентом, али са прилошком карактеристиком непроменљивости облика ${ }^{1}$ ). Отприлике - исти ток творбе у оба ова језика, с тим што је у енглеском језику за један степен једноставнији од оног у српском језику, формулом изражено:

(to) report : reportedly report-+-ed $+-l y>$ reportedly

$\downarrow$ reportedly (adverb)

\section{наводити : наводно}

навод- [-u -ти], навод- [+-ø/--ø]+-ни, -на,

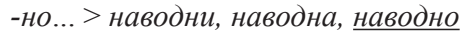
наводно (прилог)

\footnotetext{
${ }^{1}$ Реч је о основном облику, наравно - јер се у елементу ко м п а ра ц и је и прилози сврставају у променљиве речи: Петар говори једноставно : Павле говори једноставније : Ђорђе говори најједноставније.
} 
(б) И - у дискурсу: потпуни паралелизам употребе.

Па тако, на пример, Двајт Болингер (Dwight Bolinger), истичући да смо „и несвесни сведоци све већег снижавања виших реченица на облик имплицитног елемента у већој реченици”, каже: „... говорник сажима целу једну реченицу у једну реч - реченицу која би, да је изречена, морала бити главна, она којом говорник жели да влада" и наводи да је један од примера такве реализације дискурса прилог reportedly у реченици као што је Agnew was reportedly incensed at the charge [,Егњу је наводно побеснео на оптужбу”], у којој би „потпун њен облик могао бити нешто као Somebody issued a report [„,Неко је издао саопштење”], или ,the report said that Agnew was incensed at the charge” [, ,саопштење је гласило да је Егњу наводно побеснео на оптужбу”]". Он с правом закључује да се ,редуковање реченица врши већ дуго време и да је вероватно у порасту, што ће резултирати тиме да ћемо завршити тако што ћемо више подразумевати него што ћемо рећи, у складу са развојем у друштвима где људи све више знају о пословима својих суседа" (Болингер 1975: 322).

А Речник МС и Речник САНУ кажу:

п р в и, сасвим кратко (изведено из другог) - наводно прил. како кажу, како се прича, према нечијем казивању или писағу (често с призвуком сумње у тачност дотичног исказа). - Побегао, наводно, с неком распуштеницом (Речник МС 2011: 739);

други, са богатијим језичким материјалом из дужег периода савременог српског(хрватског) језика - наводно прил. како кажу, према казивању, причању или писању извесног лица (или лицй) (често са призвуком сумње у тачност дотичнога исказа). - На свадбеној гозби било је наводно више од стотину званица (Матас. 1, 38). Бјежи, по трећи пут, од куће, наводно с неком дјевојком, и долази у Париз (Томић Ј., Реп. 1960, 2-315). У време када је [...] чланак наводно био писан, у Совјетском Савезу било је и те колико остатака старе нације (Зах. 2, 192). Жене из ноћних барова причају да је галантан, јер да наводно посредује код државног привилегираног Експорта Репе (Крл. 17, 71). Месни лист био је орган трговачког удружења и [...] морао [je] да донесе [...] неку исправку: извињавао се за реч „џунгла”, да дело није било доказано и да они наводно не желе да прејудицирају одлуку суда (Перов. М., 29). Писао је он своју драму двије стотине година након што се она наводно збила (Батуш. 3, 312) (Речник САНУ 1988: 477).

3. Конструкција реченице са прилогом наводно, као кондензатором целе једне реченице, жива је посебно у актуелном дискурсу нашег журнализма. О томе сведоче, додати ранијим примерима из грађе коју дају наша два највећа речника савременог језика, примери из свакодневне штампе:

Отписани. Тако би могли сада да буду сматрани најбољи кошаркаши Србије, јер су пред немогућом мисијом. Најмање је десет разлога због којих, наводно, не могу да победе Француску, али [...] Имамо ми нешто да кажемо о томе. И наши кошаркаши (Блиц - Спорт, 2016). - Нису то само српска посла. Пре две године, сличан случај прожимао је светску штампу. Наиме, према вестима које су у септембру 2010. пренели бројни светски медији, астрофизичарка из Малезије Мазлан Олтман је н а во дн о именована за амбасадо- 
ра за свемир Уједињених нација. Главна улога овог новог УН функционера наводно је требало да буде први контакт са ванземаљцима (Време, 2012).

Исто је тако жива у англосаксонској журналистици (посебно америчкој) одговарајућа јој енглеска реченица са прилогом-кондензатором reportedly, о чему ћете у свакодневним медијима наћи потврде као што су: New York is reportedly a very exciting place to live [„„ујорк је наводно врло узбудљиво место за живот"]. - The committee is reportedly unhappy about thediscrepancy in numbers [„Комитет је наводно несрећан због несагласности бројева“]. The president is reportedly getting twitchy about the recent fall in his popularity [,Председник наводно постаје нервозан због недавног пада своје популарности”]. - The actress is reportedly very upset by the incident [,„лумица је наводно веома узнемирена због инцидента"]. - The plane was reportedly shot down by enemy aircraft [„,Авион је наводно оборен од стране непријатељског авиона"]. - 50 people have reportedly been injured in an explosion at the plastics factory [,,50 људи је наводно повређено у експлозији у фабрици пластике”] (The Cambridge Advanced Learner's Dictionary \& Thesaurus, on-line, 2016, Cambridge: University Press.) - Katharine McPhee reportedly „very upset” about Michael Morris kissing scandal [„Катарина Мекфи је наводно 'веома узнемирена' због скандала Мајкла Мориса са љубљењем”] (UPI News Service, 2013).

4. Још у првој половини XX века, много пре појаве и самог појма и термина гл о ба л и з а ц и а са данашњим његовим импликацијама, у пракси језичког подучавања у нашој друштвеној средини, неговани су страхови од утицаја „великих” језика на „мале”, па и на наш, српски језик. Страхови који би данас били усмерени, да данашњим језиком кажемо - на јачање „одбране нашег идентитета" од његовог губљења под ударом глобализације. Али већ тада су лингвисти (бар наше београдске Белићеве школе) указивали на то да се не може свака идентичност (па ни само сличност) језичких јединица - тумачити као „рђав превод са овог или оног (страног) језика” или да је „израз добијен под утицајем неког од тих језика”. Наши лингвисти су формулисали такве ставове на основама датих Белићевих учења о ј ези и к и кон стантама (в.: Белић 1998: 337-368), посебно на констатацијама да се „У основици свих језика на свету налазе [...] исте језичке константе и иста средства за њихово остваривање”, да се „у сваком језику или у свакој групи може појавити, у извесно време њихова развитка, и особина која је типична за који други језик или другу коју језичку групу”, као и да се, сходно томе, „увек [...] могу у њима развити и слична, чак и једнака средства за остварење онога што се потенцијално налази у тим условима” (Белић 1998: 354).

Тако, кад је у питању место апстрактн их и глаголских именица као „имплицитног елемента” у једној реченици (како их Болингер одређује), наша прегледна лингвистичка литература наводи да је већ „средином века, у првој половини посматраног периода 1945-1995, српска лингвистика указивала... на потребу да граматичари измене оне догматске приступе реченици који су структуру клаузе типа: делити мишљење, дакле - ону у којој је девербативна глаголска именица носилац семантичког дела предикације - дефинисали као туђе, готово неграматичке за српски језик [...], и захте- 
вали да се таква реченица 'вербализује', тј. да се изрази само предикатом, нпр., 'мислити исто' или сл.” При томе та литература констатује да је „таква структура и и стори с ки потврђена као одавно уобичајена у српском језику", као готово и у свим европским језицима (и словенским и другим), и да су „поменута указивања констатовала... припадност датих структура језичким универзалијама европских језика и аутохтону оправданост њихову и у модерном књижевном језику" (Српски језик 1996: 136), као што је то и у случајевима са именицама те (апстрактне, глаголске) семантичко-творбене категорије у падежним синтагмама уопште (в. ниже, т. 5).

5. И касније, у наредним 70-им и 80-им годинама - показује наша прегледна литература - анализама оваквих синтаксичких конструкција посвећене су студије више наших лингвиста, с њиховим посебним наглашавањем да је номинализација и врло заступљена у српском књижевном језику, као и да је он у томе равноправан са другим европским језицима, и у свакодневном дискурсу, али и у писаном дискурсу (прозне) књижевности и, посебно - у дискурсу правно-политичког, публицистичког и научног карактера.

За ово наведена литература даје примере као што су - (1) апстрактне / глаголске именице као допуне типа (директног и индиректног) обје кта: почеше разговор // са разговором (< почеше да разговарају), ступио је на рад (< почео је да ради), не зна за тугу (< не зна да тугује) ужива у раду с децом (< ужива да ради с децом) и друге такве многе допуне, у различитим падежним облицима апстрактних/глаголских именица, са примерима „имплицитног елемента" - (2) за в ременска значења: Пре поласка окренуо се своме сабеседнику (< Пре него што је пошао...), Пред спавање је читао (< Непосредно пре него што је заспао, читао је), И остаће до смрти $(<\ldots$ док не умре), После сусрета са капетан Мишом, открио је Саву (<Након ито се сусрео са капетан Мишом...), при пењағу узбрдо (<кад се пењу узбрдо), у причању (<док су причали), - (3) за узрочна значења: одбио је то из мржне (<... зато што мрзи), у жељи // са жељом да се споје (<зато што желе...), огорчен је због губитка (... зато ито је изгубио), услед недостатка финансијских средстава (< зато ито недостају финансијска средства), - (4) зазначења намерн их клауза: ради превазилажења тешкоћа $(<\ldots$ да би се превазишле тешкоће), у ичиьу измене (< ... да би изменио), - (5) за значење услова: жртва је била готово незнатна у поређењу са добитком $(<\ldots$ ако се пореди са добитком), и многи други, с различитим падежним облицима апстрактних / глаголских именица у синтагми која је „имплицитни елеменат” у реченици (в.: Српски језик 1996: 137).

6. И у закључку: сигурно је да се из овог контекста, обележеног као језичка константа, не може искључити - са гледишта морфосинтаксе посматрано - ни ко н де н з о в њ е реченица у пр и л оге, као ни - са аспекта семантике узето - импликативност тако употребљеног прилога. ${ }^{2}$

\footnotetext{
${ }^{2}$ Ово - утолико пре што у оба ова индоевропска језика морфолошки си стеми имају заступљене, у њиховим глаголским облицима, и п арт иц и пе (у енглеском - праве партиципе, а у српском - гл. прилог садашњи и гл. прилог прошли, са делом њихових некадашњих особина: ограничењем на функцију одредбе предиката), који заправо у семантичко-синтаксичком аспекту
} 
Посебно се они не могу искључити онда када су узети као критеријумске категорије де фин и с њ а језичких средстава која би била резултат глобализације и е в а л у ц и ј е њихове употребе у дискурсу многих врста (говорне и писане) комуникације у српској језичкој заједници. То на првом месту и зато што, у контексту контакта са „великим” језицима - у овом случају са енглеским језиком, на који као на најрелевантнији у процесу глобализације указују истраживачи и теоретичари домена социолингвистике - два језика у којима смо анализирали и само ову једну морфосинтаксичку конструкцију припадају истој индоевропској групи језика. Ова чињеница - не може да буде занемарљива у констатовању да ли је нешто аутохтоно или је преузето из једног језика у други језик, било у процесу глобализације, било уопште, по законитостима које владају у подручју које лингвистика дефинише појмом (и термином) језици у контакту.

\section{ГРАЂА}

Речник МС 2011: Речник српскога језика, Нови Сад: Матица српска.

Речник САНУ 1988: Речник српскохрватског књижевног и народног језика, XIII, Београд: САНУ - Институт за српскохрватски језик.

The Cambridge Advanced Learner's Dictionary \& Thesaurus, online, 2016, Cambridge: University Press.

\section{ЛИТЕРАТУРА}

Белић 1998: Александар Белић, Општа лингвистика, Изабрана дела, том 1, Београд: Завод за уџбенике и наставна средства.

Болингер 1975: Dwight Bolinger, Aspects of Language, New York: Harcourt Brace Jovanovich, Inc.

Бугарски 2009: Ранко Бугарски, Европа у језику, Библиотека XX век, Београд: - Књижара Круг.

Српски језик 1996: Српски језик на крају века (ред. М. Радовановић), Београд: Институт за српски језик САНУ и Службени гласник.

реченице представљају врсту кондензатора целе једне зависне клаузе. На пример, српска велика дескриптивно-нормативна граматика у XX веку, наводећи пример $B u \partial e \hbar u$ да је пропао свакојако, а опет желе $ћ и$ и надају $и$ се не би ли му се живот који дан продужио [...], напише сину писмо (В. С. Караџић, Историјски и етнографски списи, 6), каже да се „обликом глаголског прилога садашњег означава [...] узрок радње главног глагола. А да то значење овог облика имамо у наведеним случајевима, није тешко утврдити јер у свима њима могли бисмо употребити зависну узрочну реченицу, а да се при том смисао не промени. Очевидно би смисао остао исти када бисмо први (Вуков) пример дали у облику сложене реченице: 3 ато ит о је видео даје свакојако пропао, а опет желео и надао се не би ли му се живот који дан продужио, он напише сину писмо" (Стевановић 1986: 736-737). 
Стевановић 1986: М. Стевановић, Савремени српскохрватски језик, II. Синтакса, Београд: Научно дело.

\author{
Slavko Stanojčić
}

\title{
LANGUAGE CONSTANTS IN THE CONTEXT OF DEFINITION OF NOTION "RESULT OF GLOBALIZATION" AND ITS EVALUATIVE USAGE
}

\begin{abstract}
Summary
Paper brings the results of research of a syntactic construction by which a presumed sentence is condensed to the adverbial lexeme (Engl. reportedly and Serb. navodno), occurring as identical in both languages - English and Serbian. The research is performed in the light of much out-pointed in sociolinguistics relevant and dominant role of the first language in the processes of so-called globalization. From the perspective of a detail in semantic-syntactic constructions, departing from the presumption of given process's influence, and on the basis of general linguistics methodology in research of language phenomena, author is demonstrating the fact of autochthony of such constructions in the languages belonging to the same Indo-European languages group, as well the fact that their paralelism in at least two (and even more) languages is the result of the existence of language constants - as Serbian linguist A. Belić defined them long ago.

Key words: globalization, language constants, English, Serbian, influence, reportedly, navodno, parallelism.
\end{abstract}

